\title{
Could Norwegian fjords serve as an analogue for the future of the Svalbard fjords? State and fate of high latitude fjords in the face of progressive "atlantification"
}

\author{
Agnieszka Kujawa ${ }^{1}$ - Magdalena Łącka ${ }^{1}$ (D) Natalia Szymańska ${ }^{1}$ - Joanna Pawłowska ${ }^{1}$ Maciej M. Telesiński ${ }^{1}$. \\ Marek Zajączkowski ${ }^{1}$
}

Received: 14 December 2020 / Revised: 24 September 2021 / Accepted: 25 September 2021 / Published online: 18 October 2021

(C) The Author(s) 2021

\begin{abstract}
Benthic foraminifera are one of the most widely and abundantly distributed organisms in the fjords of Svalbard and Norway. Due to their short life span and quick reactivity to environmental changes they can be used as indicators of the "atlantification" process. Here, we compare the benthic foraminifera assemblages along the latitudinal gradient, from the fjords of northern Svalbard to southern Norway to assess whether the "atlantification" process may homogenise the foraminiferal assemblages in terms of their abundance and species composition. Furthermore, the previously published data on benthic foraminiferal faunas was updated to identify changes in distribution that have occurred over the last few decades. For this purpose, fjord mouths in western and northern Svalbard (Isfjorden, Wijdefjorden and Rijpfjorden) and northern and southern Norway (Balsfjorden, Raunefjorden and Hjeltefjorden) were resampled. The analysis revealed similarities between the Svalbard and Norwegian foraminiferal assemblages of up to 30\%; however, there were essential differences in terms of abundance and biodiversity. These results suggest that Svalbard fjords will remain distinct in the future, even under conditions of further warming or "atlantification". Svalbard fjords may be dominated by Atlantic Water- preferring species, whereas, in Norwegian fjords, pressure from human activity will probably be the main driver of environmental changes, leading to changes in the foraminiferal assemblages with the increasing dominance of opportunistic, hypoxia-tolerant species.
\end{abstract}

Keywords Benthic foraminifera $\cdot$ Atlantification $\cdot$ Norway $\cdot$ Svalbard $\cdot$ Biodiversity $\cdot$ Fjords

\section{Introduction}

Fjords are the most common coastal features in the European Arctic. They are a unique transition zone between land and open sea, which provide valuable information on climatic and environmental changes (Syvitski and Shaw 1995; Cottier et al. 2005). Svalbard fjords are particularly affected by ongoing climatic changes and are transforming faster than most other marine environments (Schiermeier 2007; Nilsen et al. 2016; Bałazy and Kukliński 2019). Until recently, Svalbard fjords were classified as subpolar, i.e. periodically freezing during winter (Syvitski et al. 1987). However, since 2005 many of these fjords have undergone

Magdalena Łącka

mlacka@iopan.pl

1 Institute of Oceanology, Polish Academy of Sciences, Powstańców Warszawy 55, 81-712 Sopot, Poland an intensified process of "atlantification" and practically do not freeze anymore (e.g. Zajączkowski et al. 2010; Cottier et al. 2019; Skogseth et al. 2020). "Atlantification" is caused by the increase in the advection of warm and saline Atlantic water (AW) carried by the West Spitsbergen Current (WSC), a continuation of the North Atlantic Current (NAC) (Walczowski et al. 2012; Muilwijk et al. 2018). The shelf of western Svalbard is cut by numerous troughs, $200 \mathrm{~m}-400 \mathrm{~m}$ deep, facilitating water exchange between open ocean and fjords. Since the core of the WSC is located at a depth of c. $500 \mathrm{~m}$, the propagation of AW towards the Svalbard fjords depends on the frequency of near-inertial waves generated by winter storms that bring the warm water from the AW layer up to the surface (Nilsen et al. 2016; Promińska et al. 2018; Graham et al. 2019). Nilsen et al. (2016) predicted that acceleration of the WSC will lead to the shallowing of the AW core and the WSC will penetrate fjords of Svalbard more easily. The "atlantification" weakens the formation of sea ice in the fjords of western and northern Svalbard (Cottier et al. 
2007; Arntsen et al. 2019), influencing the abundance and distribution of benthic fauna (Włodarska-Kowalczuk et al. 2007, 2013).

Recent research suggests that Norwegian fjords could be a modern analogue for the future of the Svalbard fjords, due to an intensive warming process (e.g. Bałazy and Kukliński 2019). Svalbard and Norway were covered by the Eurasian ice sheets during the Last Glacial Maximum, c. $20 \mathrm{ka}$ BP. Today, Norwegian fjords are classified as temperate fjords which are free of sea ice (Syvitski et al. 1987). There are also no tidewater glaciers (Andreassen et al. 2005). The benthic foraminifera distribution patterns in these fjords are shaped mainly by the surface runoff, river inflow, basin morphology and local water mass distribution (Qvale et al. 1984). Fjords can evolve from one type to another as a result of climate changes (Szczuciński et al. 2009); therefore, it is important to observe how these changes affect fjord ecosystems.

Benthic foraminifera are one of the most widely and abundantly distributed organisms of the Svalbard and Norway fjords. Due to their short life span and quick reactivity to environmental changes (Kramer and Botterweg 1991), they can potentially be used as indicators of the "atlantification" process, particularly because the bottom-water temperature is one of the most important abiotic factors controlling their distribution (Murray and Alve 2016). Studies of current foraminifera assemblages are also important to improve their use as proxies in paleoenvironmental interpretations.

In this study, benthic foraminiferal assemblages along the latitudinal gradient, from the fjords of northern Svalbard to southern Norway (from $80^{\circ} \mathrm{N}$ to $60^{\circ} \mathrm{N}$ ) were compared, to assess whether the "atlantification" process could homogenise the foraminifera assemblages of these two regions in terms of their abundance and species composition. A comprehensive benthic foraminiferal biogeography of this region was presented by Murray and Alve (2016), based on the available literature at the time (mostly from the 1990s, e.g. Hald and Korsun 1997) and on morphotaxonomy. Our study updates the existing dataset to identify possible changes in benthic foraminifera species distribution that have occurred in the past three decades. For this purpose, the mouths of the fjords in western and northern Svalbard (Isfjorden,Wijdefjorden and Rijpfjorden), as well as northern and southern Norway (Balsfjorden, Raunefjorden, Hjeltefjorden), are resampled. Fjord mouths were selected because shelf and ocean waters have a greater influence in these locations, compared to central parts and heads, which usually represent local conditions.

\section{Study region}

Study sites were selected to represent different thermal conditions along a latitudinal gradient, from the northernmost tip of Svalbard to the fjords of southern Norway (Fig. 1).
Rijpfjorden, Wijdefjorden and Isfjorden (subpolar fjords) are located in the Svalbard archipelago where the oceanographic conditions are shaped by an interplay between AW and Arctic Water (ArW) (Fig. 1A). AW is carried northward by the WSC along the continental shelf of Svalbard. In the northern part of the archipelago, the WSC diverges into the Svalbard Branch, which flows eastwards, and the Yermak Branch, which flows northwards into the Arctic Ocean (Aagaard et al. 1987). AW is relatively warm and saline $\left(\geq 3{ }^{\circ} \mathrm{C}\right.$ and $\geq 34.65$ ) (Cottier et al. 2005) (shown in Table 1), whereas ArW is between $1.0^{\circ} \mathrm{C}$ and $1.5^{\circ} \mathrm{C}$ and 34.3 and 34.8. ArW is likewise transported northward along the western coast of Svalbard by the East Spitsbergen Current (ESC), but it flows closer to the shore and becomes less saline due to outflow from the adjacent fjords (Cottier et al. 2005). The mixing of AW and ArW on the shelf leads to the formation of Transformed Atlantic Water (TAW), characterised by temperatures of $1.0^{\circ} \mathrm{C}-3.0^{\circ} \mathrm{C}$ and salinity $>34.65$ (Cottier et al. 2005; Nilsen et al. 2016). Dense Winter Cooled Water (WCW) can be found throughout the year at the bottom of the fjords' deep basins.

Rijpfjorden is a south-north-oriented fjord cutting into the northern coast of Nordaustlandet (Fig. 1A). It has the northernmost exposure of all of the studied fjords and is a true Arctic fjord that freezes every winter and is ice-covered for at least nine months a year (October - June; Ambrose et al. 2006; Cottier et al. 2019). Winds also drive drifting pack ice into the fjord during the summer months, while warm subsurface AW enters the fjord from the north (Hop et al. 2019).

Wijdefjorden is located on the northern coast of Spitsbergen and, at $108 \mathrm{~km}$, is the longest fjord in the Svalbard archipelago. Along the coast of Wijdefjorden, five tidewater glaciers are located: two at the fjord-head and three along the northeastern coast. Wijdefjorden is influenced by both AW and local waters.

Isfjorden is the largest fjord system on Svalbard; it is strongly influenced by AW that delivers heat flux and creates ice-free conditions (Nilsen et al. 2016).

Balsfjorden, Hjeltefjorden and Raunefjorden (temperate fjords) are located along the coast of Norway (Fig. 1B). The oceanographic conditions of the Norwegian coast are shaped by two currents: the Norwegian Coastal Current (NCC) and the Norwegian Atlantic Current (NwAC). They both flow northwards but are distinguished by a clear difference in salinity, and they do not mix. The NwAC carries more saline AW ( $\geq 34.9$; Table 1$)$, whereas the NCC is a wedgeshaped current that carries less saline waters $(<34.9)$, which become fresher during summer due to land runoff (Cottier et al. 2005). The current flows close to the shore and influences local fjords (Sætre 1999).

Among the three Norwegian fjords, Balsfjorden is the most northern and does not have a direct connection to the open 


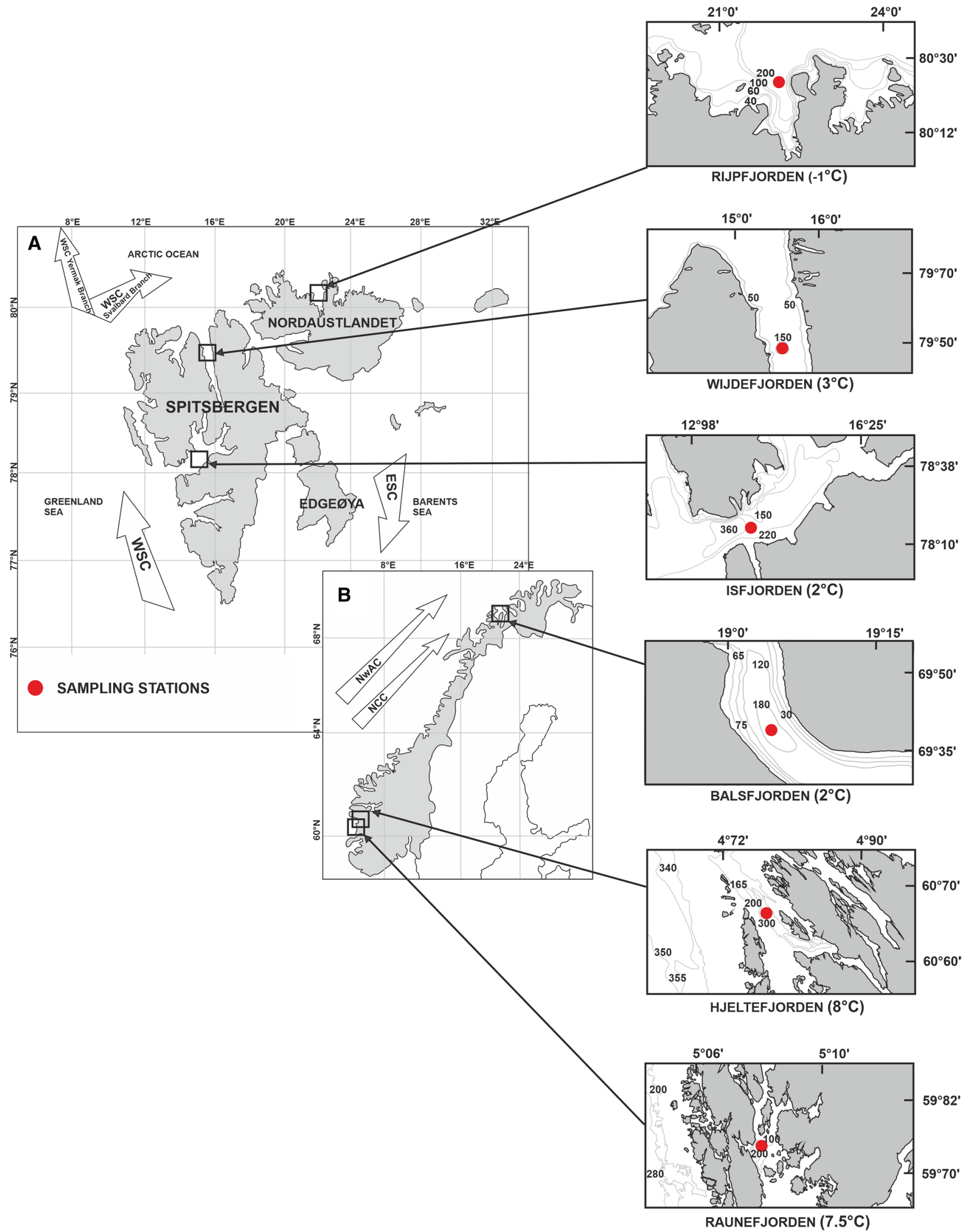

Fig. 1 Location of the sampling stations in fjords of A Svalbard and $\mathbf{B}$ Norway. Values in brackets are bottom-water temperatures at the time of sampling. WSC West Spitsbergen Current, ESC East Spitsbergen Current, NwAC Norwegian Atlantic Current, NCC Norwegian Coastal Current 
Table 1 List of water masses characteristics in studied Svalbard (after Cottier et al. 2005) and Norwegian fjords (after Hopkins 1991)

\begin{tabular}{llll}
\hline Water mass & Abbreviation & \multicolumn{2}{l}{ Characteristics } \\
\cline { 3 - 4 } & & Temperature $\left({ }^{\circ} \mathrm{C}\right)$ & Salinity \\
\hline Atlantic water & AW & $>3$ & $>34.65$ \\
Arctic water & ArW & $-1.5-1$ & $34.3-34.8$ \\
$\begin{array}{l}\text { Transformed Atlantic } \\
\quad \text { water }\end{array}$ & TAW & $1-3$ & $>34.65$ \\
$\begin{array}{lll}\text { Winter cooled water } \\
\text { Surface water }\end{array}$ & WCW & $<-0.5$ & $34.3-34.85$ \\
$\begin{array}{l}\text { Norwegian Atlantic } \\
\quad \text { water }\end{array}$ & NwAW & $>7$ & $<34$ \\
$\begin{array}{l}\text { Norwegian Coastal } \\
\text { water }\end{array}$ & NwCW & $2-13$ & $>35$ \\
\hline
\end{tabular}

sea. Water exchange occurs through three inlets: Tromsøysund, Sandnessund and Straumsfjorden. Due to its shallow sill depth $(10 \mathrm{~m}-30 \mathrm{~m})$, it is strongly influenced by coastal waters (Forwick and Vorren 2016). It is also relatively narrow, with an average width of $5 \mathrm{~km}$. It has a maximum basin depth of $130 \mathrm{~m}$ and is characterised by a flat bottom with only one sill. The sediments are mainly of glaciomarine origin, but the presentday Balsfjorden is free of tidewater glaciers (Hopkins 1991). The sea-ice cover during winter is present only in the shallow arms of the fjord (Wassmann et al. 1996).

Hjeltefjorden and Raunefjorden, located further south (Fig. 1B), are under constant pressure caused by marine traffic connecting the city of Bergen with strategic maritime passages. They are characterised by numerous inlet sills: the deepest sill (170 m) connects Hjeltefjorden with Raunefjorden, while the sills connecting these fjords with the open sea do not exceed $40 \mathrm{~m}$. In the summer, strong northern winds induce upwelling, causing denser waters to spill over the sills, resulting in salty, cold, oxygen-rich waters to fill the fjord, improving environmental conditions (Aksnes 2006). Neither of these fjords is influenced by glaciers.

All of the studied fjords are characterised by similar sedimentation rates. In the Svalbard fjords, the sedimentation rates range between $0.11 \mathrm{~cm} \mathrm{yr}^{-1}$ and $0.17 \mathrm{~cm} \mathrm{yr}^{-1}$ in Isfjorden, and usually do not exceed $0.2 \mathrm{~cm} \mathrm{yr}^{-1}$ in other large fjords (Elverhøi et al. 1995; Majewski and Zajączkowski 2007). In the Norwegian fjords, sedimentation varies between $0.13 \mathrm{~cm} \mathrm{yr}^{-1}$ and $0.28 \mathrm{~cm} \mathrm{yr}^{-1}$ (Włodarska-Kowalczuk et al. 2019).

\section{Materials and methods}

\section{Sampling}

Surface sediment samples were collected in August 2015 (Norwegian fjords) and August 2016 (Svalbard fjords)
Table 2 Coordinates of sampling stations

\begin{tabular}{llll}
\hline Station & Depth $(\mathrm{m})$ & Latitude & Longitude \\
\hline Rijpfjorden & 260 & $80^{\circ} 22.354^{\prime} \mathrm{N}$ & $22^{\circ} 05.736^{\prime} \mathrm{E}$ \\
Wijdefjorden & 160 & $79^{\circ} 29.359^{\prime} \mathrm{N}$ & $15^{\circ} 33.475^{\prime} \mathrm{E}$ \\
Isfjorden & 230 & $78^{\circ} 09.800^{\prime} \mathrm{N}$ & $14^{\circ} 07.100^{\prime} \mathrm{E}$ \\
Balsfjorden & 180 & $69^{\circ} 23.061^{\prime} \mathrm{N}$ & $19^{\circ} 02.804^{\prime} \mathrm{E}$ \\
Hjeltefjorden & 300 & $60^{\circ} 40.052^{\prime} \mathrm{N}$ & $04^{\circ} 51.734^{\prime} \mathrm{E}$ \\
Raunefjorden & 240 & $60^{\circ} 16.502^{\prime} \mathrm{N}$ & $05^{\circ} 09.075^{\prime} \mathrm{E}$ \\
\hline
\end{tabular}

during the cruises of S/Y Oceania (Fig. 1; Table 2). Sampling stations were located in the axis of the fjords to minimize direct terrigenous influence. At each station, a single $10 \mathrm{~cm}$ sediment core was taken using a small gravity corer loaded with transparent barrels $(4.5 \mathrm{~cm}$ inner diameter). Replication is mandatory for environmental monitoring (Schönfeld et al. 2012); however, this was not the focus of this study. These samples may, therefore, provide only a limited representation of spatial variability and should be treated with some caution. Directly after collection, cores were visually inspected to detect disturbances, then cut in $1 \mathrm{~cm}$ slices and the upper $2 \mathrm{~cm}$ used for further analyses. We have decided to study only the uppermost $2 \mathrm{~cm}$, and compare it with the archive data by Hald and Korsun (1997), instead of studying the entire core in terms of past changes, because vertical migration of foraminifera within the sediment up to several centimeters could provide too much distortion in such a high-resolution study. Samples for foraminiferal analyses were preserved in 75\% ethanol to which Rose Bengal solution was added to distinguish between living and dead foraminifera. Water temperature, salinity and turbidity were measured at each station with a Mini CTD Sensordata SD202, at 1-s intervals.

\section{Foraminiferal analysis}

Sediment samples for foraminiferal analyses were wet-sieved through $500 \mu \mathrm{m}, 100 \mu \mathrm{m}$ and $63 \mu \mathrm{m}$ diameter sieves. The samples were sorted dry and, when necessary, they were split using a dry microsplitter. Foraminifera from $500 \mu \mathrm{m}$ and $100 \mu \mathrm{m}$ fractions were combined, as the $500 \mu \mathrm{m}$ sieve was only used to protect smaller foraminifera from destruction by, e.g. small stones. Both living and dead fauna were studied in the $>100 \mu \mathrm{m}$ size fraction. Since dead foraminifera tests give a time-averaged view of the fauna, this will tend to smooth out some of the spatial (and temporal) patchiness and help to mitigate the problem of limitations imposed by the lack of replication. We have decided to study $>100 \mu \mathrm{m}$ fraction instead of $>125 \mu \mathrm{m}$ (Schönfeld et al. 2012) to compare our foraminiferal assemblages with the ones studied by Hald and Korsun (1997) who also used $>100 \mu \mathrm{m}$ fraction. A minimum of 300 specimens from a representative split of 
each sample were identified to precisely determine the relative abundance of species of the assemblage (Patterson and Fishbein 1989). The Rijpfjorden sample contained a lower amount of benthic foraminifera (244 specimens), therefore this sample could be less representative in further biodiversity calculations and should be treated with some caution.

Specimens were morphologically identified to the lowest possible taxonomic level, following the generic classification and taxonomy of Loeblich and Tappan (1987). Foraminiferal identification was based on the literature from the relevant regions (e.g. Alve 1991; Husum and Hald 2004; Mackensen et al. 1985; Hald and Korsun 1997; Łącka and Zajączkowski 2016). Nomenclature was according to the accepted species names published in the WoRMS database (Hayward et al. 2020). Foraminiferal abundance was expressed as the number of individuals $\mathrm{g}^{-1}$ of dry sediment [ind $\mathrm{g}^{-1}$ ]. Species that constitute at least $5 \%$ of the assemblage were considered dominants. The raw count data (total assemblage) normalized to ind $\mathrm{g}^{-1}$ was first transformed using square-root transformation. Bray-Curtis similarity between the assemblages was calculated by the Plymouth Routines in Multivariate Ecological Research (PRIMER) software version 6.0 (Clarke et al. 2006; Ding et al. 2014). Taxonomic diversity was expressed with the Shannon-Wiener index (H'):

$H^{\prime}=-\sum_{i=1}^{n} p_{i} \ln p_{i}$

where $p_{i}$ is the proportion of each specimen belonging to the $i$ th species and was calculated using Microsoft Excel Spreadsheet Software (Spellerberg and Fedor 2003). Foraminiferal species composition was analyzed using the Principal Component (PC) method, with orthogonal rotation (varimax) applied to the dataset of total (living and dead) individuals. The commercially distributed statistics package SYSTAT 11 was used for the analyses.

\section{Results}

\section{Oceanographic conditions}

In Rijpfjorden, salinity ranged from 34.5 to 35.1 and the temperature was the lowest of all of the studied fjords (ranging from $-0.4{ }^{\circ} \mathrm{C}$ at the bottom to $5{ }^{\circ} \mathrm{C}$ at the surface). A low amount of suspended particulate matter was present $(<0.4$ formazin turbidity unit [FTU]; Fig. 2).

In Wijdefjorden, salinity ranged from 21.2 at the surface to 35.5 at the bottom (Fig. 2). The temperature ranged from $5.8^{\circ} \mathrm{C}$ at the surface to $3.4{ }^{\circ} \mathrm{C}$ at the bottom. Turbidity ranged from 0.4 to $0.9 \mathrm{FTU}$ in the uppermost $20 \mathrm{~m}$, then dropped to $0.1 \mathrm{FTU}$ and increased again near the bottom, reaching c. 0.6 FTU (Fig. 2).
Surface salinity in Isfjorden $(>20 \mathrm{~m}$ ) varied from 29.4 to 34 and increased to 35.1 at c. $70 \mathrm{~m}$ (Fig. 2). The temperature ranged from $7.5^{\circ} \mathrm{C}$ at the surface to $1.8^{\circ} \mathrm{C}$ at the bottom, with a significant increase up to $4.5^{\circ} \mathrm{C}$ at a depth of $90 \mathrm{~m}-120 \mathrm{~m}$. The amount of suspended solid matter in the surface layer was the highest of all of the studied fjords, reaching 12.5 FTU (Fig. 2).

In Balsfjorden, salinity ranged from 28.7 to 33.8 and temperature oscillated between $13.6{ }^{\circ} \mathrm{C}$ at the surface and $3{ }^{\circ} \mathrm{C}$ at the bottom (Fig. 2). Water turbidity was highest in the surface layer (1.1 FTU), whereas below $35 \mathrm{~m}$ it dropped to c. 0.2 FTU.

Hjeltefjorden was characterised by salinity ranging from 29.8 at the surface to $>35$ below $125 \mathrm{~m}$ and temperature ranged from $17{ }^{\circ} \mathrm{C}$ at the surface to $7.5^{\circ} \mathrm{C}$ at the bottom. Turbidity was $0.5 \mathrm{FTU}$ at the surface and decreased to 0.1 FTU below the surface layer (Fig. 2).

Due to the strong ship drift, the measurements in Raunefjorden reached a maximum depth of $138 \mathrm{~m}$ : salinity oscillated from 28.9 to 35 and the temperature was from $18.3{ }^{\circ} \mathrm{C}$ at the surface to $7.6^{\circ} \mathrm{C}$ at the bottom. Turbidity was highest at the surface, reaching a maximum of $1.2 \mathrm{FTU}$ and decreasing to $0.3 \mathrm{FTU}$ at $138 \mathrm{~m}$ (Fig. 2).

\section{Foraminiferal assemblages}

In total, 68 foraminifera species (52 calcareous and 16 agglutinated) were found (all the raw species counts and percentages are available as the supplementary files Online Resource 1 and Online Resource 2). Examples of these are illustrated in Fig. 3 and 4. In general, a higher number of species was found in Norwegian fjords, with the highest species richness observed in Raunefjorden (40 species; Fig. 5). Among the Svalbard fjords, Wijdefjorden was characterised by the highest species richness (31 species), whereas the lowest number of species was noted in Rijpfjorden (17 species).

The fjords of Svalbard were characterised by a Shannon-Wiener index below 2.2, with the lowest diversity in Wijdefjorden (around 1.90; Fig. 5). In all Norwegian fjords, diversity was above 2.4 and the southernmost fjords, Hjeltefjorden and Raunefjorden, were characterised by the highest diversity (Fig. 5).

In the Svalbard fjords, foraminiferal abundance did not exceed 75 ind g $^{-1}$ (Fig. 6). The Norwegian fjords were characterised by much higher abundance, ranging from c. 516 ind $\mathrm{g}^{-1}$ in Raunefjorden to slightly over 167 ind $\mathrm{g}^{-1}$ in Balsfjorden. The foraminiferal assemblages were dominated by dead calcareous specimens (Fig. 6). The lowest abundances of living (stained) foraminifera were found in Hjeltefjorden (0.5\%), Raunefjorden (6.6\%) and Rijpfjorden (10.7\%). Both Svalbard and Norwegian fjords were dominated by calcareous foraminifera (Fig. 6). 
Fig. 2 Water temperature $\left[{ }^{\circ} \mathrm{C}\right]$, salinity and turbidity [FTU] measured at the sampling stations at the time of sampling in August 2015 (Norway) and in August 2016 (Svalbard). Svalbard fjords (left-hand column): Rijpfjorden, Wijdefjorden, Isfjorden; and Norwegian fjords (right-hand column): Balsfjorden, Hjeltefjorden and Raunefjorden. $A W$ Atlantic Water, ArW Arctic Water, FTU formazin turbidity unit, $T A W$ Transformed Atlantic Water, $W C W$ Winter Cooled Water, $S W$ Surface Water, NwAC Norwegian Atlantic Water, $\mathrm{NwCW}$ Norwegian Coastal Water
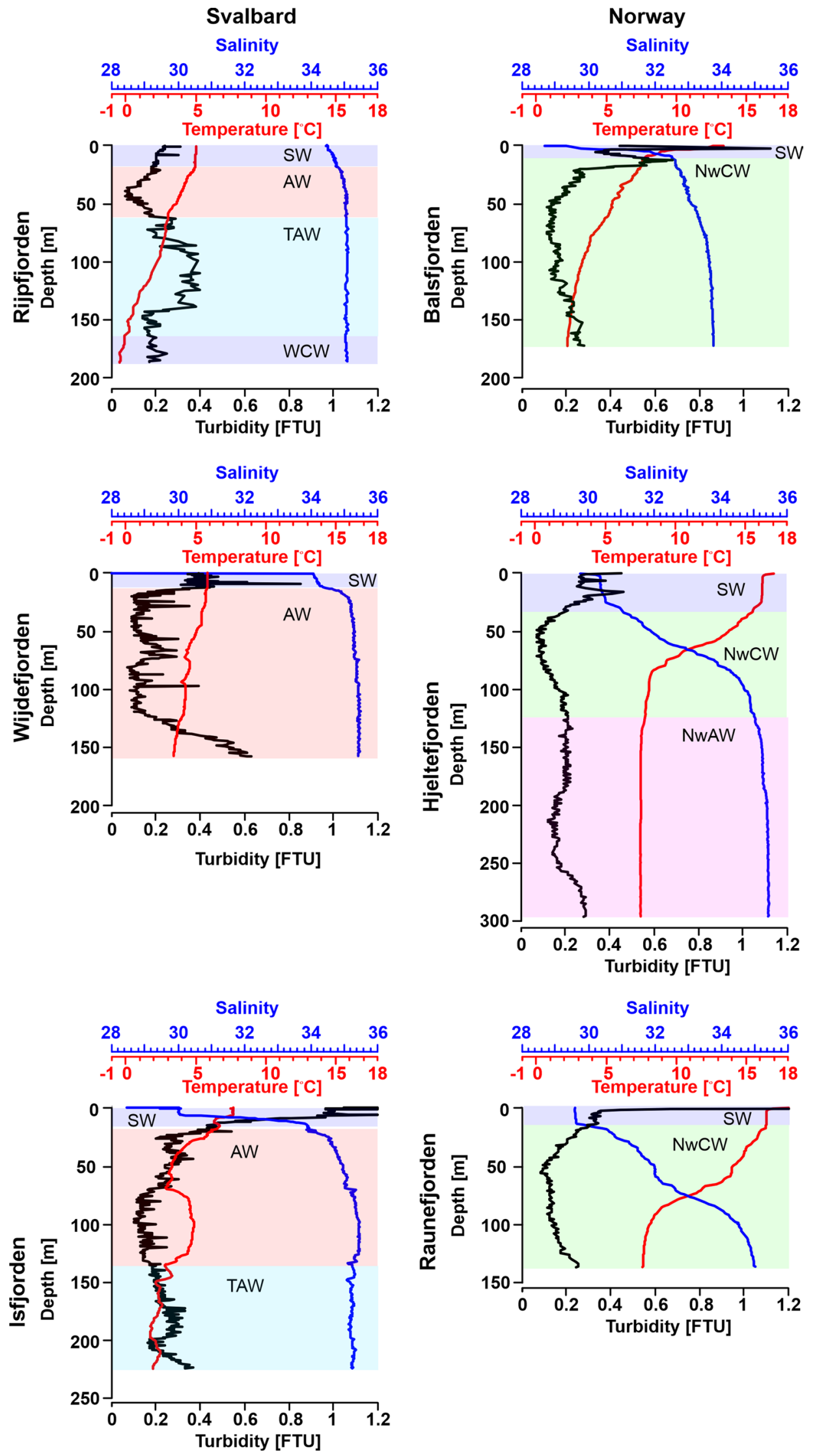
The only species that was dominant in all of the studied fjords was Cassidulina reniforme (ranging from $5.7 \%$ abundance in Raunefjorden to $26.5 \%$ in Balsfjorden; Fig. 7). Elphidium clavatum was a dominant species in Hjeltefjorden and all Svalbard fjords, whereas Cibicidoides lobatulus was a dominant species in two Svalbard (Rijpfjorden and Isfjorden) and two Norwegian fjords (Hjeltefjorden and Raunefjorden). The relative abundances of all dominant species are presented in Fig. 7.

\section{Principal component analysis}

Results of the principal component analysis (PCA) (Table 3) performed on a total assemblage showed that four components, PC1, PC2, PC3 and PC4, accounted for $93.67 \%$ of the variance within the data set. Each PC is defined by a dominant species and accessory species. PCs are referred to as FA named by the species with the highest score values (Table 3). Nonionellina labradorica FA in Isfjorden and Wijdefjorden explained $29.45 \%$ of the total foraminiferal variance, with Buccella frigida, C. lobatulus, E. clavatum, Fursenkoina complanata and Melonis affinis as accessory species. The second assemblage was found in Raunefjorden and Hjeltefjorden, where Bolivina robusta FA (4.14\%) was the most important taxon and the accessory species were Cassidulina laevigata, C. lobatulus, C. reniforme and Hyalinea balthica. PC3 and PC4 were noted only in Rijpfjorden and Balsfjorden, respectively. In Rijpfjorden, Adercotryma glomeratum FA was observed, with C. lobatulus, Trochammina inflata, E. clavatum, F. complanata, M. affinis and $N$. labradorica as accessory species, altogether accounting for $17.84 \%$ of the total variance. Cassidulina reniforme FA $(16.68 \%)$, found only in Balsfjorden, consisted of five accessory species: $F$. complanata, Globobulimina turgida, M. affinis, N. labradorica and E. clavatum (Table 3).

\section{Bray-Curtis similarity}

The Bray-Curtis analysis performed on a total assemblage revealed c. $30 \%$ similarity between all fjords. The fjords were further divided into two major groups: southern Norwegian fjords with c. $70 \%$ similarity between Raune and Hjeltefjorden; and Svalbard fjords, together with Balsfjorden, with c. $50 \%$ similarity between them (Fig. 8).

\section{Discussion}

\section{Benthic foraminiferal assemblages as evidence of the "atlantification" of Svalbard fjords}

The studied fjords show differences in foraminifera species richness and abundance, but most are dominated by $C$. reniforme and E. clavatum (except Balsfjorden and Raunefjorden, where E. clavatum constituted less than $5 \%$ of the total assemblage), confirming the ubiquitousness of these species. Murray and Alve (2016) described E. clavatum as a species with a "southern boundary" that is not present in the fjords of western Norway. However, according to our data as well as Darling et al. (2016) who found $E$. clavatum in the Skagerrak and the Kattegat, this species appears further south too.

The lowest foraminiferal abundance and species richness were recorded in Rijpfjorden, probably because of the cold WCW at the fjord bottom and the prevalence of drifting sea ice at the surface (Cottier et al. 2019). The presence of sea-ice in Rijpfjorden is also consistent with the moderate contribution of T. inflata in this assemblage (c. 7\%): this species is an indicator of seasonal sea-ice presence (e.g. Scott et al. 2009). The most abundant species in Rijpfjorden was A. glomeratum: this species thrives in cold, well-oxygenated waters (Williamson et al. 1984; Alve 1991), which is in accordance with the presence of WCW at the bottom of the fjord. Szymańska et al. (2017) suggested that this species is also associated with AW mixed with colder, local waters (i.e. TAW): this agrees with this study, which found TAW between depths of $70 \mathrm{~m}$ and $170 \mathrm{~m}$ in Rijpfjorden. The next most abundant species in this assemblage were E. clavatum and M. affinis: while E. clavatum is an opportunistic species (e.g. Corliss 1991), the appearance of $M$. affinis is, to the best of our knowledge, the first record of this species so far north in the Svalbard fjords. The northernmost locality where $M$. affinis has previously been noted, though in very low abundance, was Kongsfjorden (Jernas et al. 2018). Usually, this species appears more abundantly on the shelf and in the troughs of southern and western Svalbard, e.g. in Storfjordrenna (Łącka et al. 2015), and Laptev Sea (Taldenkova et al. 2005) as it thrives in waters of Atlantic origin (Hald and Steinsund 1996). Its appearance in Rijpfjorden suggests that this fjord experiences, at least seasonally, environmental conditions suitable for the growth of species thriving in AW. The presence of AW in the fjord's mouth was also confirmed by the CTD profile.

Rijpfjorden is regarded as a cold subpolar fjord that, for a long time, has been dominated by Arctic species (Dalpadado et al. 2016). However, according to the recent report of Cottier et al. (2019), acceleration of the AW inflow to the fjord has been observed for the last three years. The appearance of AW species in Rijpfjorden could be the first faunal indication of the "atlantification" of this northern Svalbard fjord. Although it remains cold enough for winter sea ice formation and the resulting presence of WCW, accelerated AW inflow enables the growth of foraminiferal species that prefer waters of Atlantic origin. Migration of foraminiferal species associated with warm AW may be a result of progressing 


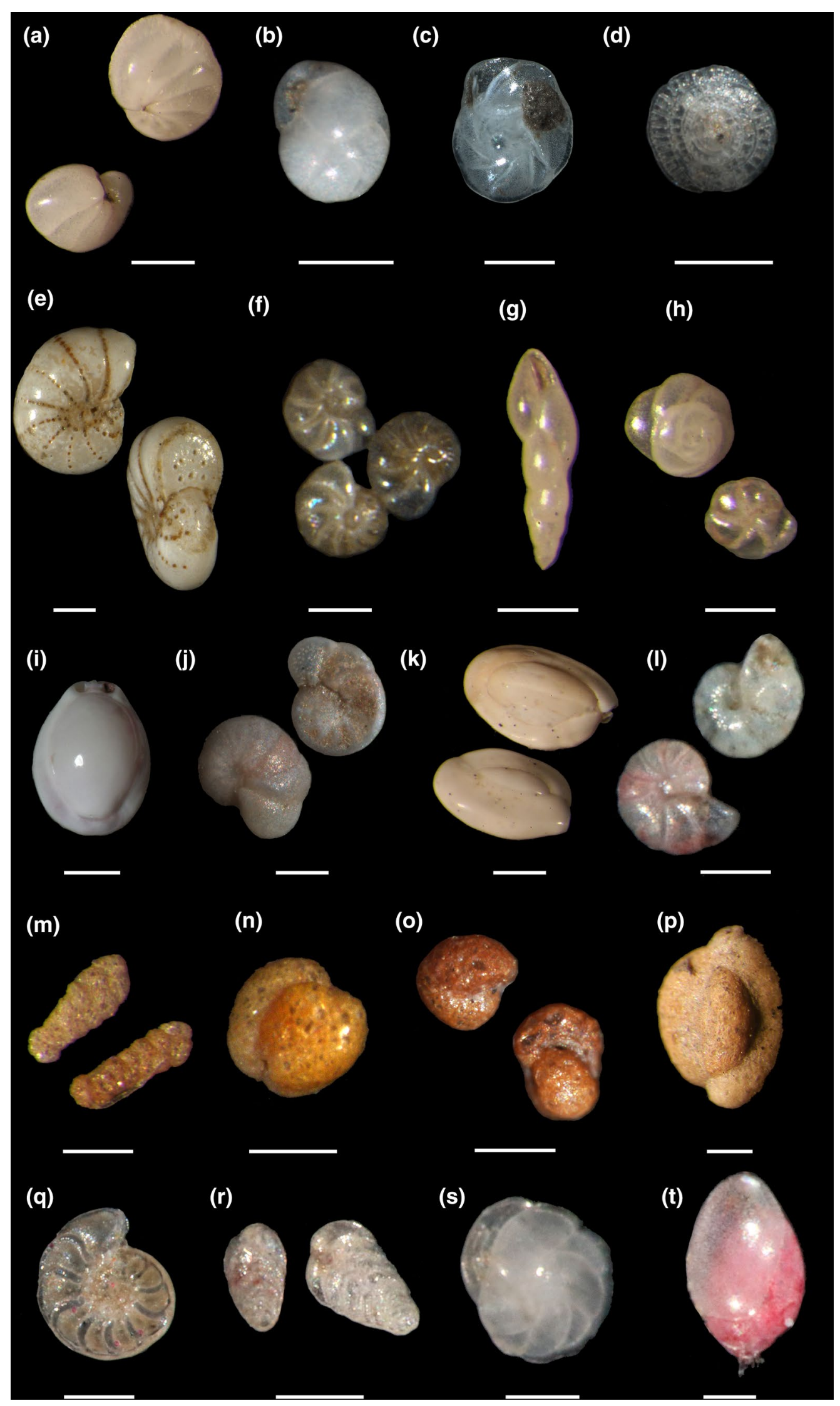


4Fig. 3 Digital images of the most abundant calcareous and agglutinated benthic foraminifera species identified in the studied Svalbard and Norwegian fjords. a Nonionellina labradorica (Dawson 1860); b Cassidulina reniforme (Nørvang 1945); c Islandiella norcrossi (Cushman 1933); d Patellina corrugata (Williamson 1858); e Elphidium bartletti (Cushman 1933); f Elphidium clavatum (Cushman 1930); g Fursenkoina complanata (Egger 1893); h Buccella frigida (Cushman 1922); i Pyrgo williamsoni (Silvestri 1923); j Cibicidoides lobatulus (Walker and Jacob 1798); k Quinqueloculina seminula (Linnaeus 1758); l Melonis affinis (Reuss 1851); m Spiroplectammina biformis (Parker and Jones 1865); n Adercotryma glomeratum (Brady 1878); o Recurvoides turbinatus (Brady 1881); p Siphonaperta agglutinata (Cushman 1917); q Hyalinea balthica (Schröter, in Gmelin 1791); r Bolivina robusta (Brady 1881); s Cassidulina laevigata (d'Orbigny 1826); t Globobulimina turgida (Bailey 1851). Scale bars equal $100 \mu \mathrm{m}$

environmental and climate changes, discussed by Murray and Alve (2016).

Wijdefjorden and Isfjorden were both dominated by the Nonionellina labradorica FAs and were similar in terms of foraminiferal abundance and number of species. The previous study on benthic foraminifera in Wijdefjorden was conducted almost three decades ago by Hald and Korsun (1997) in a similar location and at a similar water depth. A comparison with our data reveals that the bottom-water temperature in the mouth of Wijdefjorden has changed from $1.6^{\circ} \mathrm{C}$ to $3.4{ }^{\circ} \mathrm{C}$ over this period. This temperature increase has significantly influenced the FA, even though the foraminiferal abundance was similar in both study years (around 100 ind $\mathrm{g}^{-1}$ ). Nowadays, the FAs in Wijdefjorden is mostly dominated by $N$. labradorica and $E$. clavatum, with significant abundances of B. frigida and $C$. reniforme. In the study of Hald and Korsun (1997), the FA was dominated by I. norcrossi, N. labradorica, B. frigida and C. lobatulus. Both $C$. reniforme and $E$. clavatum point to a change towards a more disturbed bottom environment (e.g. Korsun et al. 1995; Łącka and Zajączkowski 2016), which is also confirmed by the high water turbidity, both at the surface and the bottom. There is also a significant decline in the abundance of I. norcrossi: in 1997, I. norcrossi, which is a typical ArW species (e.g. Majewski et al. 2009) constituted 19.6\% of the Wijdefjorden assemblage, whereas in the current study it reached only a few percent in Wijdefjorden and Rijpfjorden. The decimation of this species is most probably related to the recent increase in AW in this fjord.

Isfjorden was also analysed by Hald and Korsun (1997). All parameters (water temperature, foraminiferal abundance and species composition) were very similar, suggesting that this environment has not changed significantly. The FA consists mainly of species associated with AW, i.e. N. labradorica (Hald and Korsun 1997; Jernas et al. 2018), but with a significant contribution of TAW-related species, e.g. A. glomeratum, which has been positively correlated with the presence of TAW entering the inner bays of Isfjorden, i.e. Adventfjorden (Szymańska et al. 2017; Kucharska et al. 2019). As Isfjorden is widely open to the main flow of the WSC, it has been constantly influenced by AW since at least the early 1990s. The influence of AW in fjord mouths on benthic FAs is also confirmed by the data from Kongsfjorden, another wide-open west Svalbard fjord (Hald and Korsun 1997). In the mouth of the Krossfjorden-Kongsfjorden system, a FA dominated by the AW-related species $N$. labradorica, with a significant contribution of E. clavatum and $C$. lobatulus, was identified. Jernas et al. (2018) revisited the station at Kongsfjorden between 2005 and 2008 and found similar assemblages.

It is important to note that besides the bottom-water temperature, the quantity of organic matter (OM) in the sediments is one of the most important abiotic factors known to influence benthic foraminifera distribution, however we did not measure it in our study. The amount of OM in the sediments has been proven to impact foraminiferal assemblages in such environments as deltas and continental shelf (e.g. Eberwein and Mackersen 2006; Koho et al. 2008; Mojtahid et al. 2009). However, Norwegian and Svalbard fjords are recognized as hot spots for organic carbon burial (Smith et al. 2015; Faust and Knies 2019; Szymańska et al. 2021) and thus the quantity of OM is highly unlikely to be a limiting factor for foraminiferal assemblages in the studied fjords.

\section{The state of modern Norwegian fjords}

The Norweigan fjords were characterised by higher abundances of foraminifera than the Svalbard fjords, as well as a higher Shannon-Wiener diversity index. The high foraminiferal abundance, especially in the southern fjords, concurs with the surveys of Sweetman et al. (2009) that found unusually abundant foraminifera and biomass in deep Norwegian fjords (c. 203,000 ind $\mathrm{m}^{-2}$ ) as well as by Szymanska et al. $\left(2021 ;>10,000\right.$ ind $\left.\mathrm{g}^{-1}\right)$. According to Wassmann et al. (1996), Norwegian fjords are characterised by relatively high water temperatures and no glacier-caused disturbance. These environmental conditions, together with high organic matter input (e.g. from agriculture), may be the reason for the observed abundance and biodiversity of foraminifera.

The dominant species in Balsfjorden was the opportunistic $C$. reniforme, associated with AW indicators like N. labradorica, B. frigida and M. affinis (Hald and Steinsund 1996; Hald and Korsun 1997; Murray and Alve 2016; Zajączkowski et al. 2010). Moreover, species with a strong tolerance for the oxygen-deficient environment, i.e. F. complanata (Kaiho 1994) and G. turgida (Kuhnt et al. 2014; Risgaard-Petersen et al. 2006) were also observed. Typically anoxic-tolerant species were also noted in Hjelte- and Raunefjorden; however, G. turigida was replaced here by $B$. robusta and $H$. balthica, whose thin test walls are an adaptation to low oxygen concentrations 
Fig. 4 Scanning electron microscope (SEM) images of selected calcareous benthic foraminifera species identified in the studied Svalbard fjords. a Elphidium clavatum (Cushman 1930); b Nonionellina labradorica (Dawson 1860); c Cibicidoides lobatulus (Walker and Jacob 1798); d Cassidulina laevigata (d'Orbigny 1826); e Islandiella norcrossi (Cushman 1933); f Cassidulina reniforme (Nørvang 1945); g Fursenkoina complanata (Egger 1893); h Trifarina fluens (Todd, in Cushman and McCulloch 1948); i Triloculina frigida (Lagoe 1977)

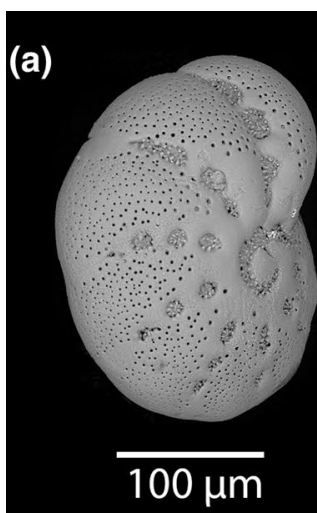

(b)
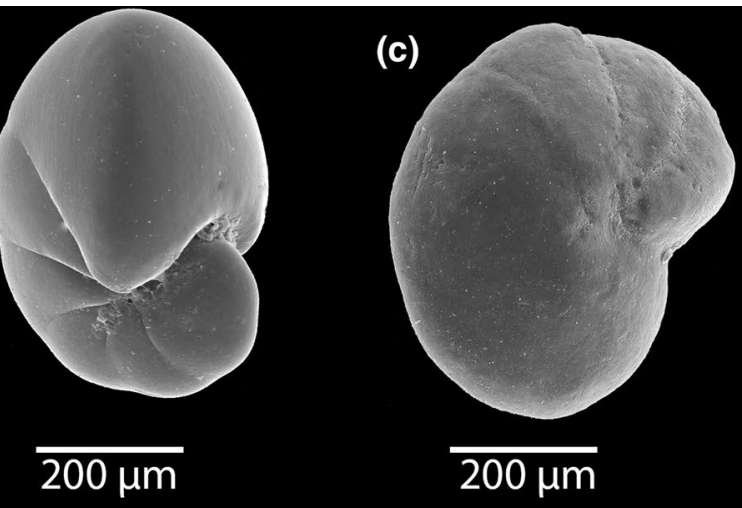

(d)

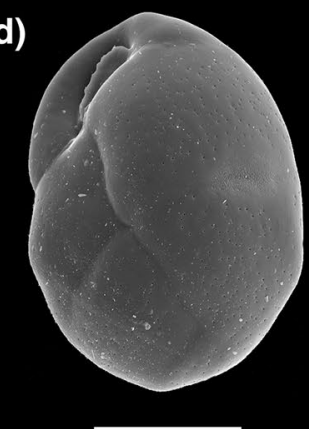

$50 \mu \mathrm{m}$

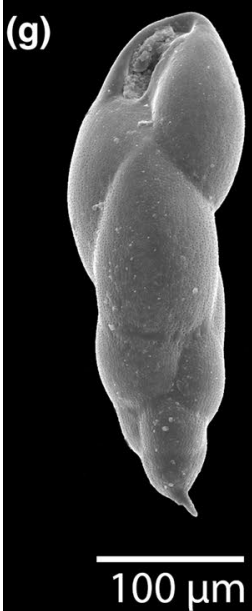

(e)

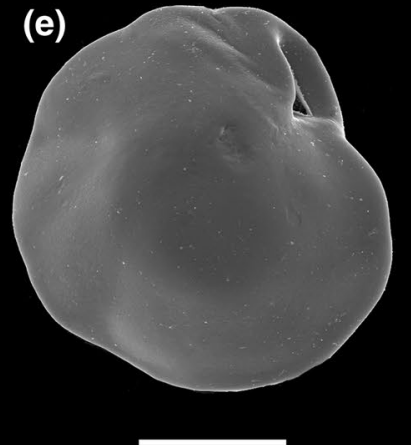

$100 \mu \mathrm{m}$

(h)

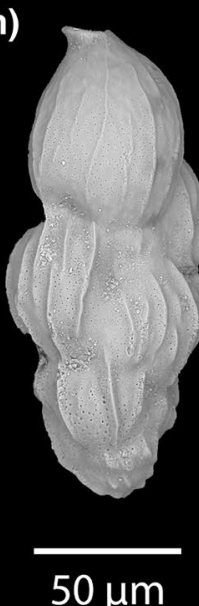

(f)

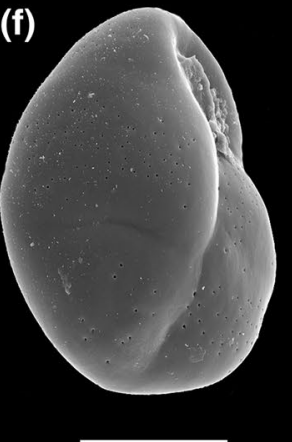

$50 \mu \mathrm{m}$

(i)

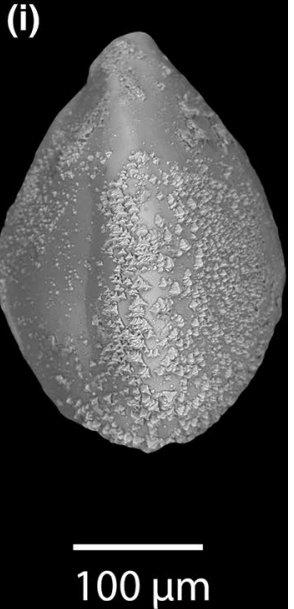

as they facilitate gas exchange (Gupta and Machain-Castillo 1993). The low numbers of living specimens found in the Norwegian fjords could, therefore, be explained by regular hypoxic conditions. Anoxic episodes, coupled with high primary production in summer, and human-induced eutrophication, are caused by e.g. salmon farming and agriculture (Aure and Stigebrandt 1990; Dale et al. 1999; Levin et al. 2009). The low number of living specimens in the southern fjords could also be the result of maritime traffic in this area causing localised heavy metal pollution (Aksnes 2006). This has been confirmed by the study of
Dijkstra et al. (2017) that found no living foraminifera in the Hammerfest harbour (northern Norway).

\section{Norwegian fjords as an analogue for the future of Svalbard fjords}

Recent research has suggested that the Norwegian fjords can serve as a modern analogue to the future of the Svalbard fjords (e.g. Bałazy and Kukliński 2019). However, comparing the studied benthic FAs and the environmental conditions in the Svalbard and Norway fjords, more differences 


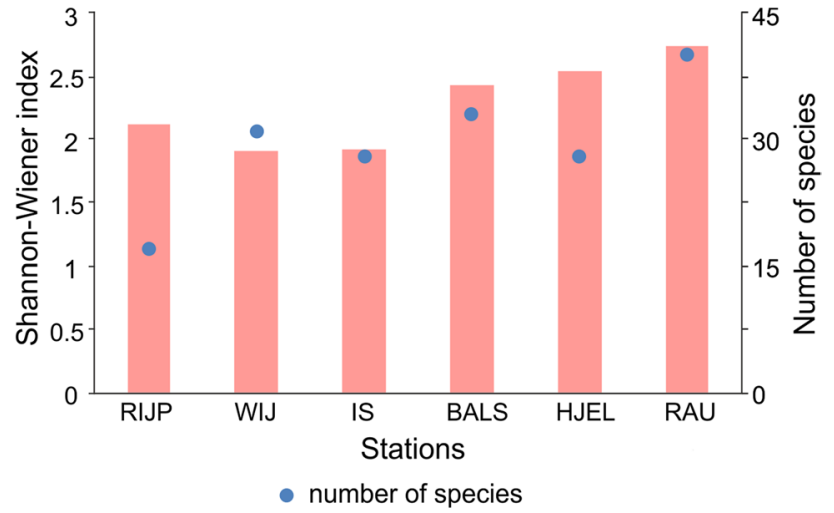

Fig. 5 Shannon-Wiener index calculated for foraminiferal assemblages and number of species counted in the studied samples. Svalbard: Rijpfjorden (RIJP), Wijdefjorden (WIJ) and Isfjorden (IS); Norway: Balsfjorden (BALS), Hjeltefjorden (HJEL) and Raunefjorden (RAU)

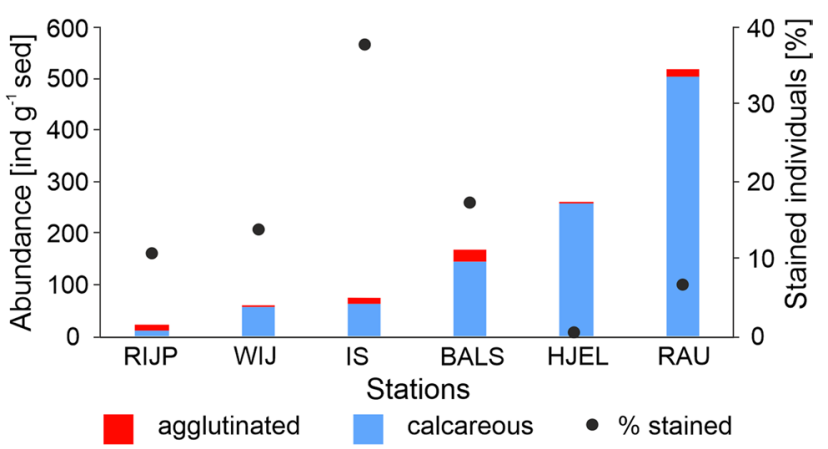

Fig. 6 The abundance of total foraminifera (agglutinated and calcareous; ind $\mathrm{g}^{-1}$ ) in the studied fjords with indicated percentage of stained calcareous individuals; Svalbard: Rijpfjorden (RIJP), Wijdefjorden (WIJ) and Isfjorden (IS); Norway: Balsfjorden (BALS), Hjeltefjorden (HJEL) and Raunefjorden (RAU)

than similarities were identified between them. The similarities and differences between these two environments are listed in Table 4 and briefly discussed below.

The main features common to both regions are the presence of AW at the fjords' mouths, the lack of sea ice (except Rijpfjorden where the sea ice appears seasonally; Hop et al. 2019) and the presence of AW foraminiferal species. However, the AW that appears in all of the studied fjords reveals different features. Besides the fact that AW loses part of its warmth to the atmosphere on its way to higher latitudes, it is also intensively mixed with local waters on the shelf before it enters the fjord. Even though Svalbard fjords are glaciated, the majority of the freshwater produced during the summer melting season remains in the glacier bays (Drewnik et al. 2016; Promińska et al. 2018). The situation is different in the Norwegian fjords as they are not glaciated. Instead, Norway is characterised by extremely high precipitation, especially during the autumn months. Strong westerly winds bring moist air from the ocean, which falls in the form of rain/snow across most of Norway. Coastal areas can receive more than $3500 \mathrm{~mm}$ annually (Hanssen-Bauer et al. 2019), whereas the annual precipitation on Svalbard is around $400 \mathrm{~mm}$ (Førland et al. 2011). High precipitation in Norway, coupled with high river and surface discharge (Wassmann et al. 1996), results in a high volume of freshwater entering the fjords along their entire length. Thus, at the Norwegian sampling stations, surface and bottom-water salinities were lower than in the Svalbard fjords. Moreover, in the Norwegian fjords, the sill often separates the fjord basin from the ocean, which hinders water exchange, whereas the Svalbard fjords are wide open to the AW inflows, which also determines the FAs in these fjords.

The hydrographic isolation of the Norwegian fjords, coupled with their relatively high productivity (both natural and agricultural driven), might lead to hypoxic conditions at the bottom of the fjords. This is confirmed by the high abundance of hypoxia-tolerant species, e.g. B. robusta, $F$. complanata, and G. turgida (Gupta and Machain-Castillo 1993). Model data suggests further deterioration of oxygen conditions in deep Norwegian fjord basins because of reduced ventilation due to warming and increased density stratification (Aksnes et al. 2019), as well as nutrient availability enhancement (Levin et al. 2009). Spring blooms naturally occur from March to April in the coastal zone of Norway and an additional increase in primary production from May to June was noted by Wassmann et al. (1996), probably as a result of freshwater runoff. Primary production is low for the rest of the year; however, the deep penetration of sunlight and the lack of wind-driven vertical mixing appears to support the growth of phytoplankton cells during blooms (Townsend et al. 1992). Dijkstra et al. (2017) state that hypoxic conditions may also be associated with the urbanisation and industrialisation of the Norwegian coasts, leading to pollution of coastal waters, thus changing the ecological quality of the environment. As a result, faunal communities in these areas often differ from those in undisturbed conditions.

Murray and Alve (2016) also examined the differences in the number and biodiversity of foraminifera from Svalbard and Norwegian fjords, specifically the environmental preferences of these organisms and the temperature and salinity of both regions. Norwegian waters are warmer (around $6{ }^{\circ} \mathrm{C}$ $-8{ }^{\circ} \mathrm{C}$ at the bottom) than Svalbard waters (around $4{ }^{\circ} \mathrm{C}$ at the bottom), which is primarily a result of their geographical position and insolation. Both regions, however, are changing significantly under the present climate warming. The results of this study suggest that in Svalbard fjords, changes will occur as the warming or "atlantification" progresses: Svalbard fjords may be dominated by AW-preferring species, with the simultaneous disappearance/migration of typical 


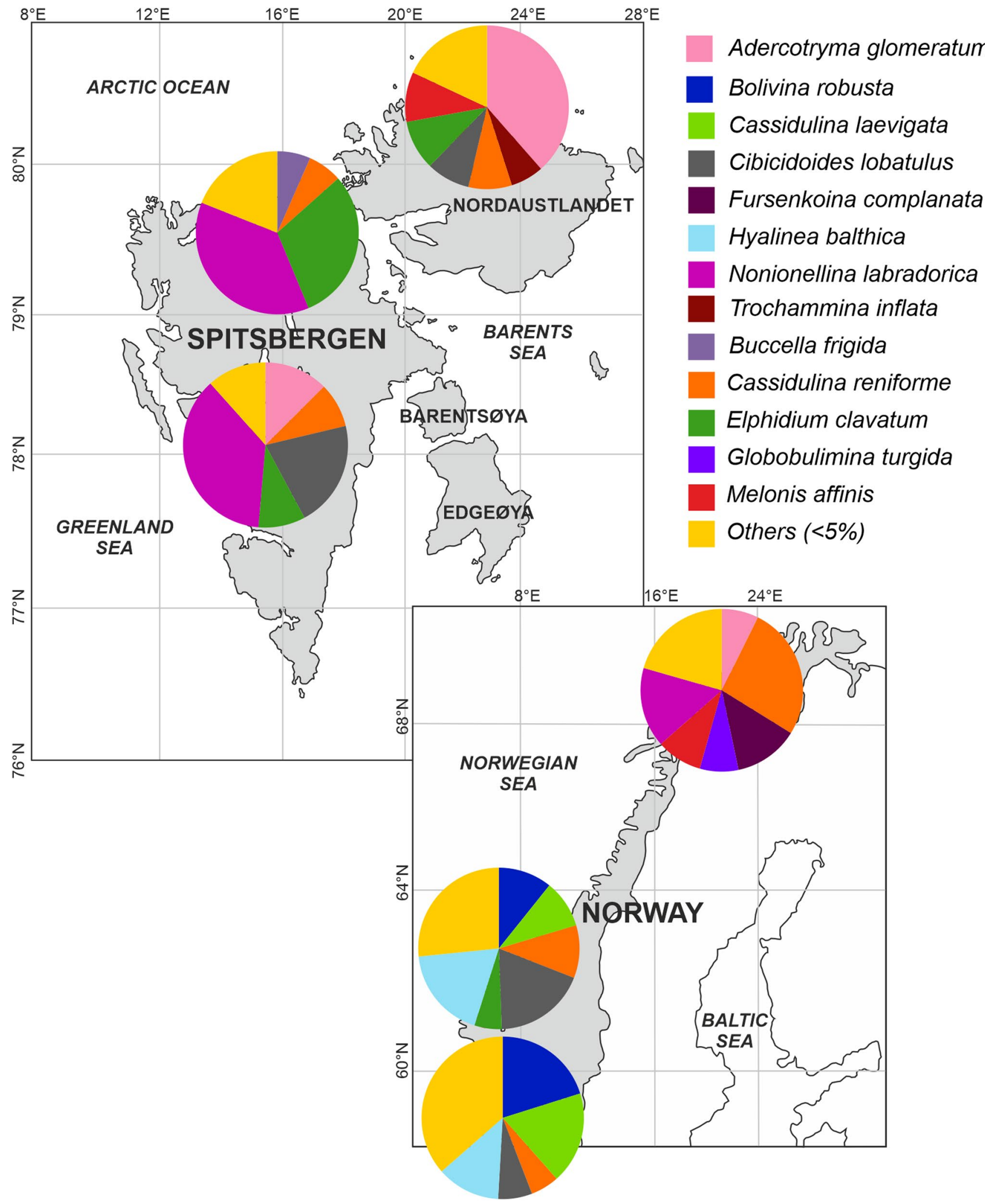

Fig. 7 Relative abundances of dominant foraminifera species $(>5 \%)$ identified in the studied fjords 
Table 3 Foraminiferal principal component (PC) scores

\begin{tabular}{|c|c|c|c|c|}
\hline & PC1 & PC2 & PC3 & PC4 \\
\hline$\%$ explained variance & 29.452 & 29.694 & 17.837 & 16.684 \\
\hline \multicolumn{5}{|l|}{ Agglutinated species } \\
\hline Adercotryma glomeratum & -0.070 & -0.641 & 7.305 & 0.263 \\
\hline Ammodiscus sp. & -0.196 & -0.388 & 0.042 & -0.264 \\
\hline Ammotium cassis & -0.182 & -0.384 & -0.119 & -0.236 \\
\hline Archimerismus subnodosus & -0.197 & -0.299 & -0.213 & -0.228 \\
\hline Cuneata arctica & -0.215 & -0.392 & -0.223 & -0.071 \\
\hline Eggerelloides advenus & -0.155 & -0.381 & -0.195 & -0.227 \\
\hline Labrospira crassimargo & 0.199 & -0.280 & -0.297 & -0.367 \\
\hline Quinqueloculina stalkeri & -0.145 & -0.385 & -0.212 & -0.234 \\
\hline Recurvoides turbinatus & -0.099 & -0.395 & 091 & 0.390 \\
\hline Reophax scorpiurus & -0.244 & -0.428 & -0.303 & 0.355 \\
\hline Siphonaperta agglutinata & -0.195 & -0.386 & -0.209 & -0.171 \\
\hline Spiroplectammina biformis & -0.123 & -0.396 & 0.101 & -0.305 \\
\hline Spiroplectinella wrighti & -0.209 & -0.083 & -0.226 & -0.253 \\
\hline Textularia earlandi & -0 & -0.393 & -0.057 & -0.225 \\
\hline Trochammina inflata & -0.233 & -0.392 & 1.080 & -0.461 \\
\hline Trochammina nana & -0.189 & -0.354 & -0.206 & -0.223 \\
\hline \multicolumn{5}{|l|}{ Calcareous species } \\
\hline Astrononion hamadaense & -0.205 & -0.243 & & -0.234 \\
\hline Bolivina earlandi & -0.235 & -0.266 & -0.238 & 0.011 \\
\hline Bolivina pygmaea & -0.213 & -0.188 & -0.229 & -0.239 \\
\hline Bolivina robusta & -0.476 & 4.142 & -0.500 & -0.680 \\
\hline Bolivinellina pseudopunctata & -0.123 & -0.358 & -0.206 & -0.24 \\
\hline Buccella frigida & 0.741 & -0.414 & -0.349 & 0.029 \\
\hline Bulimina marginata & -0.245 & 0.088 & -0.261 & -0.267 \\
\hline Cassidulina laevigata & -0.534 & 3.675 & -0.379 & -0.265 \\
\hline Cassidulina neoteretis & 0.129 & -0.250 & 0.123 & -0.423 \\
\hline Cassidulina reniforme & -0.187 & 1.351 & 0.412 & 6.104 \\
\hline Cassidulina sp. & -0.213 & -0.188 & -0.229 & -0.239 \\
\hline Chilostomellina fimbriata & -0.195 & -0.386 & -0.209 & -0.171 \\
\hline Cibicidoides lobatulus & 1.542 & 3.175 & 1.866 & -0.626 \\
\hline Cibicidoides wuellerstorfi & -0.193 & -0.327 & -0.209 & -0.226 \\
\hline Cornuspira involvens & -0.195 & -0.386 & -0.209 & -0.17 \\
\hline Dentalina frobisherensis & -0.165 & -0.384 & -0.207 & -0.227 \\
\hline Discorbis vilardeboanus & -0.178 & 0.387 & -0.197 & -0.319 \\
\hline Elphidium bartletti & -0.135 & -0.385 & -0.210 & -0.236 \\
\hline Elphidium clavatum & 3.976 & 0.128 & 1.016 & -1.790 \\
\hline Elphidium sp. & -0.155 & -0.383 & -0.205 & -0.230 \\
\hline Evolvocassidulina tenuis & -0.179 & 0.095 & -0.198 & -0.282 \\
\hline Favulina squamosa & -0.180 & -0.330 & -0.197 & -0.228 \\
\hline Fissurina sp. & -0.230 & 0.556 & -0.246 & -0.282 \\
\hline Fursenkoina complanata & -0.898 & -0.603 & -0.718 & 3.355 \\
\hline Gavelinopsis praegeri & -0.187 & -0.328 & -0.203 & -0.227 \\
\hline Glandulina laevigata & -0.185 & -0.382 & -0.202 & -0.221 \\
\hline Globobulimina auriculata & -0.155 & -0.383 & -0.205 & -0.230 \\
\hline Globobulimina turgida & -0.585 & 0.316 & -0.581 & 1.799 \\
\hline Globocassidulina crassa & -0.243 & 0.181 & -0.254 & -0.185 \\
\hline $\begin{array}{l}\text { Globocassidulina subglo- } \\
\text { bosa }\end{array}$ & -0.248 & 0.162 & -0.261 & -0.228 \\
\hline
\end{tabular}

Table 3 (continued)

\begin{tabular}{|c|c|c|c|c|}
\hline & PC1 & PC2 & PC3 & PC4 \\
\hline Hyalinea balthica & -0.214 & 4.063 & -0.256 & -0.680 \\
\hline Islandiella helenae & -0.233 & -0.422 & 0.562 & -0.129 \\
\hline Islandiella norcrossi & -0.045 & -0.366 & 0.559 & -0.334 \\
\hline Lagena striata & -0.165 & -0.384 & -0.207 & -0.227 \\
\hline Melonis affinis & -0.795 & 0.123 & 1.392 & 1.880 \\
\hline Nonionella auricula & -0.215 & -0.247 & -0.228 & -0.184 \\
\hline Nonionellina labradorica & 6.619 & -0.381 & -1.196 & 1.905 \\
\hline Nonionoides turgidus & -0.209 & -0.361 & -0.220 & -0.124 \\
\hline Oolina borealis & -0.165 & -0.384 & -0.207 & -0.227 \\
\hline Patellina corrugata & -0.193 & -0.327 & -0.209 & -0.226 \\
\hline Procerolagena distoma & -0.199 & -0.358 & -0.213 & -0.174 \\
\hline Pullenia bulloides & -0.245 & -0.124 & -0.250 & -0.052 \\
\hline Pullenia elegans & -0.189 & -0.354 & -0.206 & -0.223 \\
\hline Pyrgo williamsoni & -0.175 & -0.387 & -0.214 & -0.178 \\
\hline Quinqueloculina seminula & -0.185 & -0.391 & -0.221 & -0.128 \\
\hline Robertina arctica & -0.155 & -0.383 & -0.205 & -0.230 \\
\hline Robertinoides charlottensis & -0.214 & -0.404 & -0.248 & 0.068 \\
\hline Stainforthia fusiformis & 0.336 & -0.424 & 0.008 & -0.454 \\
\hline Stainforthia loeblichi & -0.187 & -0.328 & -0.203 & -0.227 \\
\hline Trifarina fluens & -0.066 & -0.245 & -0.281 & -0.097 \\
\hline Triloculina trihedra & -0.175 & -0.382 & -0.200 & -0.223 \\
\hline Uvigerina peregrina & -0.212 & 0.371 & -0.230 & -0.309 \\
\hline
\end{tabular}

Significant species scores for particular foraminiferal assemblages (FAs) are in bold

PC analyses were performed on the entire (living and dead) FAs

ArW species. In Norwegian fjords, the pressure from human activity will probably be the main driver of environmental changes, leading to changes in FAs with a dominance of opportunistic, hypoxia-tolerant, and eutrophication-friendly species.

\section{Summary and conclusions}

- This analysis of benthic foraminiferal assemblages of fjords along the latitudinal gradient from northern Svalbard to southern Norway, reveals that similarity between the studied assemblages reaches up to $30 \%$. However, there are crucial differences, in terms of abundance and biodiversity.

- The presence of M. affinis in Rijpfjorden is the first-ever observation of this AW-thriving species so far north. This observation confirms the conclusion of Cottier et al. (2019) that, in recent years, Rijpfjorden is more susceptible to AW inflows. Shrinking sea-ice cover and more frequent storms have led to an intense inflow of AW onto the shelf and further to the western and northern Svalbard fjords, enabling AW species to appear further north. 


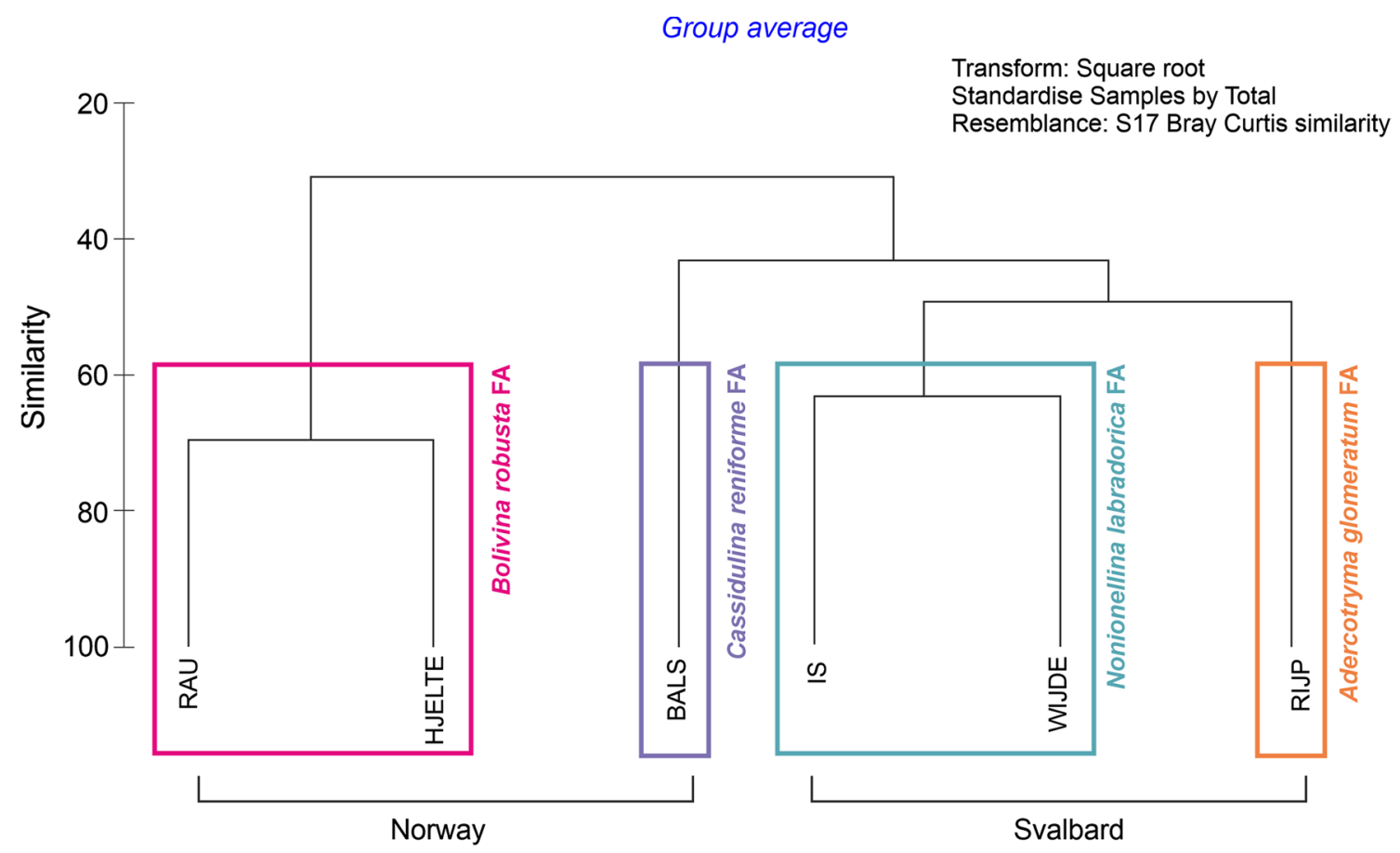

Fig. 8 Bray-Curtis similarity of total foraminiferal assemblages (FA). Svalbard: Rijpfjorden (RIJP), Wijdefjorden (WIJ) and Isfjorden (IS); Norway: Balsfjorden (BALS), Hjeltefjorden (HJEL) and Raunefjorden (RAU), with principal component analysis FA and dominant species indicated

Table 4 List of similarities and differences between Svalbard and Norwegian fjords

\begin{tabular}{ll}
\hline Similarities & Differences \\
\hline $\begin{array}{l}\text { Environmental factors } \\
\text { The presence of Atlantic Water }\end{array}$ & $\begin{array}{l}\text { Fjord morphology } \\
\text { Back of sea-ice }\end{array}$ \\
& $\begin{array}{l}\text { Insolation } \\
\text { Surface discharge } \\
\text { Productivity } \\
\text { Precipitation } \\
\text { Oxygenation of bottom-waters } \\
\text { Anthropogenic stress }\end{array}$ \\
& Length of the vegetation period \\
Benthic foraminifera & Abundance \\
Presence of Atlantic Water indica- & \\
tors and opportunistic species & Biodiversity \\
& Number of living specimens \\
& Presence of anoxic-water species
\end{tabular}

- There was a significant decimation of the typical ArW species, I. norcrossi, in Widefjorden (compared with the study of Hald and Korsun (1997)), related to the recent "atlantification" of this fjord.

- The two southernmost Norwegian fjords, Hjelte- and Raunefjorden were characterised by a low percentage of living foraminifera individuals, potentially resulting from anthropogenic stress and/or hypoxic conditions in these fjords.

- In recent years, the greatest change in the benthic foraminifera communities is observed in the Svalbard fjords that have been, until recently, regarded as the subpolar fjords, with the presence of seasonal sea-ice cover and limited inflow of AW. On the other hand, the Svalbard fjords that have constantly had AW inflow do not change significantly.

- Changes related to global warming will not make Svalbard fjords similar to Norwegian fjords because of significant differences in insolation resulting from the geographic position, precipitation and ease of water exchange with the adjacent shelf. In the future, Svalbard fjords may be dominated by AW-preferring species, whereas in Norwegian fjords the pressure from human activity will probably be the main driver of environmental changes. This may lead to changes in the foraminifera assemblages towards the dominance of opportunistic, hypoxia-tolerant species.

Supplementary Information The online version contains supplementary material available at https://doi.org/10.1007/s00300-021-02951-z.

Acknowledgements This research was financed by the National Science Centre in Poland, projects no. 2016/23/N/ST10/01351 (Svalbard samples collection and analysis) and 2016/23/N/ST10/01382 
(Norwegian samples collection and analysis). Marek Zajączkowski's and Magdalena Łącka's participation in this study was supported by the National Science Centre in Poland, project No. 2019/33/B/ ST10/00297. We express our thanks to the captain and crew of the R/V Oceania. We wish to thank Sergei Korsun, Andrew Gooday, and an anonymous reviewer for the comments that helped to improve the paper considerably.

Authors' contributions AK, MŁ, NS, JP, MT and MZ conducted the field work and data collection. AK, MŁ and NS wrote the manuscript. All authors were involved in editing various versions of the manuscript.

Funding This research was financed by the National Science Centre in Poland, projects No. 2016/23/N/ST10/01351 (Svalbard samples collection and analysis) and 2016/23/N/ST10/01382 (Norwegian samples collection and analysis). Marek Zajączkowski's and Magdalena Łącka's participation in this study was supported by the National Science Centre in Poland, Project No. 2019/33/B/ST10/00297.

\section{Declarations}

Conflict of interest The authors declare no conflicts of interest.

Open Access This article is licensed under a Creative Commons Attribution 4.0 International License, which permits use, sharing, adaptation, distribution and reproduction in any medium or format, as long as you give appropriate credit to the original author(s) and the source, provide a link to the Creative Commons licence, and indicate if changes were made. The images or other third party material in this article are included in the article's Creative Commons licence, unless indicated otherwise in a credit line to the material. If material is not included in the article's Creative Commons licence and your intended use is not permitted by statutory regulation or exceeds the permitted use, you will need to obtain permission directly from the copyright holder. To view a copy of this licence, visit http://creativecommons.org/licenses/by/4.0/.

\section{References}

Aagaard K, Foldvik A, Hillman S (1987) The West Spitsbergen Current: Disposition and water mass transformation. J Geophys Res 92:3778-3784. https://doi.org/10.1029/JC092iC04p03778

Aksnes GS (2006) A study of the renewal of bottom water in Hjeltefjorden using observational data and a $\sigma$-coordinate ocean model. Dissertation, University of Bergen

Aksnes DL, Aure J, Johansen PO, Johnsen GH, Salvanes AGV (2019) Multi-decadal warming of Atlantic water and associated decline of dissolved oxygen in a deep fjord. Estuar Coast Shelf Sci 228:106392. https://doi.org/10.1016/j.ecss.2019.106392

Alve E (1991) Benthic foraminifera in sediment cores reflecting heavy metal pollution in Sorfjord, western Norway. J Foraminiferal Res 21:1-19. https://doi.org/10.2113/gsjfr.21.1.1

Ambrose WG Jr, Carroll ML, Greenacre M, Thorrold SR, McMahon KW (2006) Variation in Serripes groenlandicus (Bivalvia) growth in a Norwegian high-Arctic fjord: Evidence for local-and largescale climatic forcing. Glob Change Biol 12:1595-1607. https:// doi.org/10.1111/j.1365-2486.2006.01181.x

Andreassen L, Elvehøy H, Kjøllmoen B, Engeset R, Haakensen N (2005) Glacier mass-balance and length variation in Norway. Ann Glaciol 42:317-325. https://doi.org/10.3189/1727564057 81812826
Arntsen M, Sundfjord A, Skogseth R, Błaszczyk M, Promińska A (2019) Inflow of warm water to the inner Hornsund fjord, Svalbard; exchange mechanisms and influence on local sea ice cover and glacier front melting. J Geophys Res Oceans 124:1915-1931. https://doi.org/10.1029/2018JC014315

Aure J, Stigebrandt A (1990) Quantitative estimates of the eutrophication effects of fish farming on fjords. Aquaculture 90:135-156. https://doi.org/10.1016/0044-8486(90)90337-M

Bałazy P, Kukliński P (2019) Year-to-year variability of epifaunal assemblages on a mobile hard substrate- Case study from high latitudes. Mar Ecol 39:e12533. https://doi.org/10.1111/maec.12533

Clarke R, Somerfield J, Chapman G (2006) On resemblance measures for ecological studies, including taxonomic dissimilarities and a zero-adjusted Bray-Curtis coefficient for denuded assemblages. J Exp Mar Biol Ecol 330:55-80. https://doi.org/ 10.1016/j.jembe.2005.12.017

Corliss BH (1991) Morphology and microhabitat preferences of benthic foraminifera from the northwest Atlantic Ocean. Mar Micropaleontol 17:195-236. https://doi.org/10.1016/03778398(91)90014-W

Cottier F, Tverberg V, Inall M, Svendsen H, Nilsen F, Griffiths C (2005) Water mass modification in an Arctic fjord through cross-shelf exchange: The seasonal hydrography of Kongsfjorden. Svalbard J Geophys Res Oceans. https://doi.org/10. 1029/2004JC002757

Cottier FR, Nilsen F, Inall ME, Gerland S, Tverberg V, Svendsen H (2007) Wintertime warming of an Arctic shelf in response to large-scale atmospheric circulation. Geophys Res Lett. https:// doi.org/10.1029/2007GL029948

Cottier F, Skogseth R, David D, Berge J (2019) Temperature timeseries in Svalbard fjords. A contribution from the "Integrated Marine Observatory Partnership". In: Orr et al. (ed) The State of Environmental Science in Svalbard report 2018. Svalbard Integrated Arctic Earth Observing System, Longyearbyen, pp $108-118$

Dale B, Thorsen TA, Fjellsa A (1999) Dinoflagellate cysts as indicators of cultural eutrophication in the Oslofjord, Norway. Estuar Coast Shelf Sci 48:371-382. https://doi.org/10.1006/ecss.1999.0427

Dalpadado P, Hop H, Rønning J, Pavlov V, Sperfeld E, Buchholz F, Rey A, Wold A (2016) Distribution and abundance of euphausiids and pelagic amphipods in Kongsfjorden, Isfjorden and Rijpfjorden (Svalbard) and changes in their relative importance as key prey in a warming marine ecosystem. Polar Biol 39:1765-1784. https:// doi.org/10.1007/s00300-015-1874-x

Darling KF, Schweizer M, Knudsen KL, Evans KM, Bird C, Roberts A et al (2016) The genetic diversity, phylogeography and morphology of Elphidiidae (Foraminifera) in the Northeast Atlantic. Mar Micropaleontol 129:1-23. https://doi.org/10.1016/j.marmi cro.2016.09.001

Dijkstra N, Junttila J, Skirbekk K, Carroll J, Husum K, Hald M (2017) Benthic foraminifera as bio-indicators of chemical and physical stressors in Hammerfest harbor (Northern Norway). Mar Pollut Bull 114:384-396. https://doi.org/10.1016/j.marpolbul.2016.09. 053

Ding F, Wu D, Zhang Q, Zheng J, Zhou Q (2014) Characterization of eubacterial and archaeal community diversity in the pit mud of Chinese Luzhou-flavor liquor by nested PCR-DGGE. World J of Microbiol Biotechnol 30:605-612. https://doi.org/10.1007/ s11274-013-1472-4

Drewnik A, Węsławski JM, Włodarska-Kowalczuk M, Łącka M, Promińska A, Zaborska A, Gluchowska M (2016) From the worm's point of view. I: Environmental settings of benthic ecosystems in Arctic fjord (Hornsund, Spitsbergen). Polar Biol 39:14111424. https://doi.org/10.1007/s00300-015-1867-9

Eberwein A, Mackensen A (2006) Regional primary productivity differences off Morocco (NW-Africa) recorded by modern benthic 
foraminifera and their stable carbon isotopic composition. DeepSea Res I: Oceanogr Res Pap 53:1379-1405. https://doi.org/10. 1016/j.dsr.2006.04.001

Elverhøi A, Andersen ES, Dokken T, Hebbeln D, Spielhagen R, Svendsen JI, Sørflaten M, Rørnes A, Hald M, Forsberg CF (1995) The Growth and Decay of the Late Weichselian Ice Sheet in Western Svalbard and Adjacent Areas Based on Provenance Studies of Marine Sediments. Quat Res 44:303-316. https://doi.org/10.1006/ qres.1995.1076

Faust JC, Knies J (2019) Organic matter sources in North Atlantic fjord sediments. Geochem Geophys 20:2872-2885. https://doi.org/10. 1016/j.csr.2014.07.008

Førland EJ, Benestad R, Hanssen-Bauer I, Haugen JE, Skaugen TE (2011) Temperature and precipitation development at Svalbard 1900-2100. Adv Meteorol 2011:893790. https://doi.org/10.1155/ 2011/893790

Forwick M, Vorren TO (2016) Deglaciation history and post-glacial mass movements in Balsfjord, northern Norway. Polar Res 21:259-266. https://doi.org/10.3402/polar.v21i2.6486

Graham RM, Itkin P, Meyer A, Sundfjord A, Spreen G, Smedsrud LH, Liston GE, Cheng B, Cohen L, Divine D, Fer I, Fransson A, Gerland S, Haapala J, Hudson SR, Johansson AM, King J, Merkouriadi I, Peterson AK, Provost C, Randelhoff A, Rinke A, Rösel A, Sennéchael N, von Walden P, Duarte P, Assmy P, Steen H, Granskog MA (2019) Winter storms accelerate the demise of sea ice in the Atlantic sector of the Arctic Ocean. Sci Rep 9:9222. https://doi.org/10.1038/s41598-019-45574-5

Gupta BKS, Machain-Castillo ML (1993) Benthic foraminifera in oxygen-poor habitats. Mar Micropaleontol 20:183-201. https:// doi.org/10.1016/0377-8398(93)90032-S

Hald M, Steinsund P (1996) Benthic foraminifera and carbonate dissolution in the surface sediments of the Barents and Kara Seas. Surface-sediment composition and sedimentary processes in the central Arctic Ocean and along the Eurasian Continental Margin. Ber Polarforsch 212:285-307

Hald M, Korsun S (1997) Distribution of modern benthic foraminifera from fjords of Svalbard European Arctic. J Foraminiferal Res 27:101-122. https://doi.org/10.2113/gsjfr.27.2.101

Hanssen-Bauer I, Førland EJ, Hisdal H, Mayer S, Sand $\varnothing$ AB, Sorteberg A (2019) Climate in Svalbard 2100 - a knowledge base for climate adaptation. Norwegian Centre for Climate Services (NCCS) for Norwegian Environment Agency (Miljødirektoratet), Norway

Hayward BW, Coze FL, Vandepitte L, Vanhoorne B (2020) Foraminifera in the world register of marine species (Worms) taxonomic database. J Foraminiferal Res 50:291-300. https://doi.org/10. 2113/gsjfr.50.3.291

Hop H, Assmy P, Wold A, Sundfjord A, Daase M, Duarte P, Kwaśniewski S, Głuchowska M, Wiktor JM, Tatarek A, Wiktor J Jr, Kristiansen S, Fransson A, Chierici M, Vihtakari M (2019) Pelagic ecosystem characteristics across the atlantic water boundary current from rijpfjorden, svalbard, to the arctic ocean during summer (2010-2014). Front Mar Sci 6:181. https://doi.org/10. 3389/fmars.2019.00181

Hopkins T (1991) The GIN Sea-A synthesis of its physical oceanography and literature review 1972-1985. Earth-Sci Rev 30:175-318. https://doi.org/10.1016/0012-8252(91)90001-V

Husum K, Hald M (2004) Modern foraminiferal distribution in the subarctic Malangen fjord and adjoining shelf, northern Norway. J Foraminiferal Res 34(1):34-48. https://doi.org/10.2113/0340034

Jernas P, Klitgaard-Kristensen D, Husum K, Koc N, Tverberg V, Louberec P, Prinsd M, Dijkstra N, Głuchowska M (2018) Annual changes in Arctic fjord environment and modern benthic foraminiferal fauna: Evidence from Kongsfjorden, Svalbard. Glob Planet Change 163:119-140. https://doi.org/10.1016/j.gloplacha. 2017.11.013
Kaiho K (1994) Benthic foraminiferal dissolved-oxygen index and dissolved-oxygen levels in the modern ocean. Geology 22:719-722. https://doi.org/10.1130/0091-7613(1994)022<0719:BFDOIA> 2.3.CO;2

Koho KA, García R, de Stigter HC, Epping E, Koning E (2008) Kouwenhoven TJ, van der Zwaan GJ. Prog Oceanogr 79:55-82. https://doi.org/10.1016/j.pocean.2008.07.004

Korsun SA, Pogodina IA, Forman SL, Lubinski DJ (1995) Recent foraminifera in glaciomarine sediments from three arctic fjords of Novaja Zemlja and Svalbard. Polar Res 14:15-31. https://doi. org/10.3402/polar.v14i1.6648

Kramer K, Botterweg J (1991) Aquatic, biological early warning systems: an overview. In: Jeffrey D, Madden N (eds) Bioindicators and Environmental Management. Academic Press, London, pp 95-126

Kucharska M, Kujawa A, Łącka M, Pawłowska J, Szymańska N, Zajączkowski M (2019) Seasonal variability of benthic foraminifera assemblages in Adventfjorden, Spitsbergen. Polar Biol 42:569-580. https://doi.org/10.1007/s00300-018-02453-5

Kuhnt T, Schiebel R, Schmiedl G, Milker Y, Mackensen A, Friedrich O (2014) Automated and manual analyses of the pore densityto-oxygen relationship in Globobulimina turgida (Bailey). J Foraminiferal Res 44:5-16. https://doi.org/10.2113/gsjfr.44.1.5

Łącka M, Zajączkowski M, Forwick M, Szczuciński W (2015) Late Weichselian and Holocene paleoceanography of Storfjordrenna, southern Svalbard. Clim past 11:587-603. https://doi.org/10.5194/ cp-11-587-2015

Łącka M, Zajączkowski M (2016) Does the recent pool of benthic foraminiferal tests in fjordic surface sediments reflect interannual environmental changes? The resolution limit of the foraminiferal record. Ann Soc Geol Pol 86:59-71. https://doi.org/10.14241/ asgp.2015.019

Levin LA, Ekau W, Gooday AJ, Jorissen F, Middelburg JJ, Naqvi SWA, Neira C, Rabalais NN, Zhang J (2009) Effects of natural and human-induced hypoxia on coastal benthos. Biogeosciences Discuss 6:3563-3654. https://doi.org/10.5194/bg-6-2063-2009

Loeblich AR, Tappan H (1987) Foraminiferal genera and their classification. Von Nostrand Reinhold Co., New York

Mackensen A, Sejrup HP, Jansen E (1985) The distribution of living benthic foraminifera on the continental slope and rise off southwest Norway. Mar Micropaleontol 9(4):275-306

Majewski W, Zajączkowski M (2007) Benthic foraminifera in Adventfjorden, Svalbard: last 50 years of local hydrographic changes. J Foraminiferal Res 2:19-28. https://doi.org/10.2113/gsjfr.37.2.107

Majewski W, Szczuciński W, Zajączkowski M (2009) Interactions of Arctic and Atlantic water-masses and associated environmental changes during the last millennium, Hornsund (SW Svalbard). Boreas 38:529-544. https://doi.org/10.1111/j.1502-3885.2009. 00091.x

Mojtahid M, Jorissen F, Lansard B, Fontanier C, Bombled B, Rabouille C (2009) Spatial distribution of live benthic foraminifera in the Rhône prodelta: Faunal response to a continental-marine organic matter gradient. Mar Micropaleontol 70:177-200. https://doi.org/ 10.1016/j.marmicro.2008.12.006

Muilwijk M, Smedsrud L, Ilicak M, Drange H (2018) Atlantic Water heat transport variability in the 20th century Arctic Ocean from a global ocean model and observations. J Geophys Res Oceans 123:8159-8179. https://doi.org/10.1029/2018JC014327

Murray J, Alve E (2016) Benthic foraminiferal biogeography in NW European fjords: A baseline for assessing future change. Estuar Coast Shelf Sci 181:218-230. https://doi.org/10.1016/j.ecss.2016. 08.014

Nilsen F, Skogseth R, Vaardal-Lunde J, Inall M (2016) A simple shelf circulation model-intrusion of Atlantic water on the West Spitsbergen Shelf. J Phys Oceanogr 46:1209-1230. https://doi.org/10. 1175/JPO-D-15-0058.1 
Patterson RT, Fishbein E (1989) Re-examination of the statistical methods used to determine the number of point counts needed for micropaleontological quantitative research. J Paleontol 63:245-248

Promińska A, Falck E, Walczowski W (2018) Interannual variability in hydrography and water mass distribution in Hornsund, an Arctic fjord in Svalbard. Polar Res 37:495-546. https://doi.org/10.1080/ 17518369.2018.1495546

Qvale G, Markussen B, Thiede J (1984) Benthic foraminifers in fjords: Response to water masses. Nor J Geol 64:235-249

Risgaard-Petersen N, Langezaal AM, Ingvardsen S, Schmid MC, Jetten MSM, den Camp HJMO, Derksen JWM, Pina-Ochoa E, Eriksson SP, Nielsen LP, Revsbech NP, Cedhagen T, van der Zwaan GJ (2006) Evidence for complete denitrification in a benthic foraminifer. Nature 443:93-96. https://doi.org/10.1038/nature05070

Sætre R (1999) Features of the central Norwegian shelf circulation. Cont Shelf Res 19:1809-1831. https://doi.org/10.1016/S02784343(99)00041-2

Schiermeier Q (2007) The new face of the Arctic. Nature 446:133-135. https://doi.org/10.1038/446133a

Schönfeld J, Alve E, Spezzaferri S (2012) The FOBIMO (FOraminiferal BIo-MOnitoring) initiative-Towards a standardised protocol for soft-bottom benthic foraminiferal monitoring studies. Mar Micropaleontol 9495:1-13. https://doi.org/10.1016/j.marmicro. 2012.06.001

Scott DB, Schell T, St-Onge G, Rochon A, Blasco S (2009) Foraminiferal assemblage changes over the last 15,000 years on the Mackenzie-Beaufort Sea Slope and Amundsen Gulf. Implications for past sea ice conditions. Paleoceanography, Canada. https://doi. org/10.1029/2007PA001575

Skogseth R, Olivier LLA, Nilsen F, Falck E, Fraser N, Tverberg V, Ledang AB, Vader A, Jonassen MO, Søreide J, Cottier F, Berge J, Ivanov BV, Falk-Peterssen S (2020) Variability and decadal trends in the Isfjorden (Svalbard) ocean climate and circulation-An indicator for climate change in the European Arctic. Prog Oceanogr 187:102394. https://doi.org/10.1016/j.pocean.2020.102394

Smith RW, Bianchi TS, Allison M, Savage C, Galy V (2015) High rates of organic carbon burial in fjord sediments globally. Nat Geosci 8:450-453. https://doi.org/10.1038/ngeo242

Spellerberg I, Fedor P (2003) A tribute to Claude Shannon (19162001) and a plea for more rigorous use of species richness, species diversity and the "Shannon-Wiener" Index. Glob Ecol Biogeogr 12:177-179. https://doi.org/10.1046/j.1466-822X.2003.00015.x

Sweetman A, Sommer S, Pfannkuche O, Witte U (2009) Retarded response by macrofauna-size foraminifera to phytodetritus in a deep Norwegian fjord. J Foraminiferal Res 39:15-22. https://doi. org/10.2113/gsjfr.39.1.15

Syvitski J, Burrell D, Skei J (1987) Fjords Processes and Products. Springer-Verlag, New York

Syvitski J, Shaw J (1995) Sedimentology and geomorphology of fjords. In: Perillo GME (ed) Developments in Sedimentology: Geomorphology and Sedimentology of Estuaries. Elsevier, Amsterdam, pp 113-178

Szczuciński W, Zajączkowski M, Scholten J (2009) Sediment accumulation rates in subpolar fjords - Impact of post-Little Ice Age glaciers retreat, Billefjorden, Svalbard. Estuar Coast Shelf Sci 85:345-356. https://doi.org/10.1016/j.ecss.2009.08.021

Szymańska N, Pawłowska J, Kucharska M, Kujawa A, Łącka M, Zajączkowski M (2017) Impact of shelf-transformed waters (STW) on foraminiferal assemblages in the outwash and glacial fjords of Adventfjorden and Hornsund, Svalbard. Oceanologia 59:525-540. https://doi.org/10.1016/j.oceano.2017.04.006

Szymańska N, Łącka M, Koziorowska-Makuch K, Kuliński K, Pawłowska J, Kujawa A, Telesiński MM, Zajączkowski M (2021) Foraminifera-derived carbon contribution to sedimentary inorganic carbon pool: A case study from three Norwegian fjords. Geobiology. https://doi.org/10.1111/gbi.12460

Taldenkova E, Bauch HA, Stepanova A, Dem'yankov S, Ovsepyan A (2005) Last postglacial environmental evolution of the Laptev Sea shelf as reflected in molluscan, ostracodal, and foraminiferal faunas. Global Planet Change 48:223-251. https://doi.org/10.1016/j. gloplacha.2004.12.015

Townsend D, Keller M, Sieracki M, Ackelson S (1992) Spring phytoplankton blooms in the absence of vertical water column stratification. Nature 360:59-62. https://doi.org/10.1038/360059a0

Walczowski W, Piechura J, Goszczko I, Wieczorek P (2012) Changes in Atlantic water properties: an important factor in the European Arctic marine climate. ICES J Mar Sci 69:864-869. https://doi. org/10.1093/icesjms/fss068

Wassmann P, Svendsen H, Keck A, Reigstad M (1996) Selected aspects of the physical oceanography and particle fluxes in fjords of northern Norway. J Mar Sys 8:53-71. https://doi.org/10.1016/09247963(95)00037-2

Williamson MA, Keen CE, Mudie PJ (1984) Foraminiferal distribution on the continental margin off Nova Scotia. Mar Micropaleontol 9:219-239. https://doi.org/10.1016/0377-8398(84)90014-8

Włodarska-Kowalczuk M, Szymelfenig M, Zajączkowski M (2007) Dynamic sedimentary environments of an Arctic glacier-fed river estuary (Adventfjorden, Svalbard). II: Meio- and macrobenthic fauna. Estuar Coast Shelf Sci 74:274-284. https://doi.org/10. 1016/j.ecss.2007.04.017

Włodarska-Kowalczuk M, Pawłowska J, Zajączkowski M (2013) Do foraminifera mirror diversity and distribution patterns of macrobenthic fauna in an Arctic glacial fjord? Mar Micropaleontol 103:30-39. https://doi.org/10.1016/j.marmicro.2013.07.002

Włodarska-Kowalczuk M, Mazurkiewicz M, Górska B, Loïc MN, Jankowska E, Zaborska A (2019) Organic Carbon Origin, Benthic Faunal Consumption, and Burial in Sediments of Northern Atlantic and Arctic Fjords (60-81 $\left.{ }^{\circ} \mathrm{N}\right)$. J Geophys Res Biogeosci. https://doi.org/10.1029/2019JG005140

Zajączkowski M, Nygård H, Hegseth E, Berge J (2010) Vertical flux of particulate matter in an arctic fjord: the case of lack of the sea - ice cover in Adventfjorden 2006-2007. Polar Biol 33:223-239. https://doi.org/10.1007/s00300-009-0699-x

Publisher's Note Springer Nature remains neutral with regard to jurisdictional claims in published maps and institutional affiliations. 